\title{
19. DISTRIBUTION, ORIGIN, AND HYDROCARBON POTENTIAL OF ORGANIC MATTER IN SEDIMENTS FROM THE PACIFIC MARGIN OF SOUTHERN MEXICO ${ }^{1}$
}

\author{
Colin P. Summerhayes and Debbie Gilbert, Exxon Production Research Company, Houston, Texas
}

\section{INTRODUCTION}

As part of an ongoing program of organic geochemical studies of sediments recovered by the Deep Sea Drilling Project, we have analyzed the types, amounts, and thermal alteration indices of organic matter collected from the Pacific continental margin of southern Mexico on Leg 66 (Figure 1; Tables 1 and 2). The samples were pieces of core frozen aboard ship. Some of them were analyzed by pyrolysis (Table 3 ), heavy $\mathrm{C}_{15}+$ hydrocarbons, and nonhydrocarbons (Table 4) to help determine their origin and hydrocarbon potential.

Our main objectives were to find out how much organic matter was being deposited; to establish whether it derived from marine or terrestrial sources; to determine the controls of deposition of organic matter; to estimate the hydrocarbon potential of the drilled section; and to compare and contrast organic sedimentation here with that on other margins (Japan margin, Gilbert et al., in press; California margin, Gilbert and Summerhayes, in press a; and Gulf of California margins, Gilbert and Summerhayes, in press b).

As shown in Figure 1, the samples come from a downslope transect that crosses the Mexican continental margin and ends in the Middle America Trench.

At most of these sites (Moore, Watkins, et al., 1979; and site reports, this volume) there is an undeformed Quaternary blanket of hemipelagic muds. It overlies lithologically different Tertiary sediments that may, at some sites, be structurally deformed. These lithostratigraphic changes reflect changes in depositional process and/or tectonically initiated changes in water depth.

\section{TYPE AND AMOUNT OF ORGANIC MATTER}

The total organic carbon (here referred to as TOC) content of the samples was measured by a LECO carbon analyzer, after samples had been treated with dilute $\mathrm{HCl}$ to remove carbonate minerals. The different types of organic matter were identified optically using a classification system devised by Masran and Pocock (in press), from slides prepared in the manner described by Staplin (1969, and Table 1). Regional and stratigraphic variations in organic facies can be seen most clearly from the averages of the organic matter composition for the different time slices (Table 2).

\footnotetext{
${ }^{1}$ Initial Reports of the Deep Sea Drilling Project, Volume 66
}

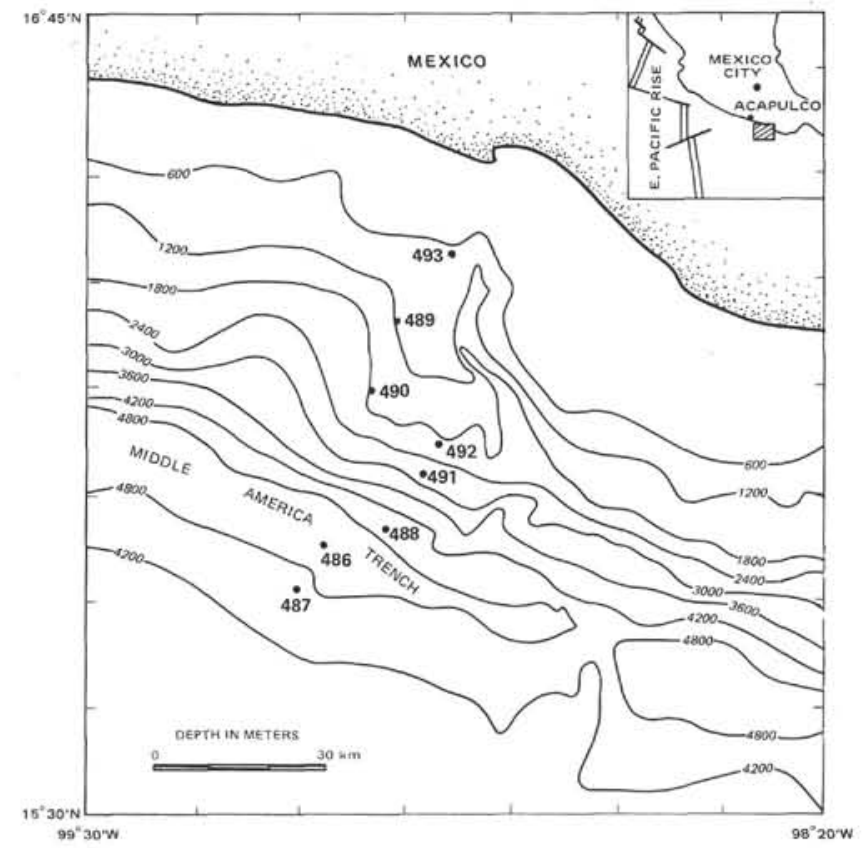

Figure 1. Location of Leg 66 DSDP drill sites off southern Mexico.

\section{Deep Sea Pelagic Facies}

At the bottom of Hole 487 is a Miocene brown pelagic clay unit. It was deposited slowly (approx. 31 $\mathrm{m} / \mathrm{m}$.y.; site chapters), what little organic matter it contains $(0.08 \%$ TOC), is mainly terrestrially derived plant material (Tables 1 and 2). Shipboard analysis shows that TOC's are less than $0.5 \%$ throughout this unit.

\section{Trench Facies}

If we think of the Middle America Trench as being the broad depression defined by 4200 meter contour (Fig. 1), then both Sites 487 and 488 are located in the trench. The organic facies of their Quaternary sections are fairly similar (we are not including here the sandy section from the base of Site 488 that is represented by our Sample 488-42-2, Table 1). Both terrestial and amorphous components are abundant, and there is a minor structured marine component (Tables 1 and 2). We consider the facies to be a mixed terrestrial-amorphous one.

At Site 487 the Quaternary sediments were probably deposited from suspension at the distal edges of turbid flows generated by turbidity currents (see site chapter); 
Table 1. Age, lithology, sedimentation rate (SR), organic matter, and thermal alteration index (TAI) of DSDP samples from Leg 66 .

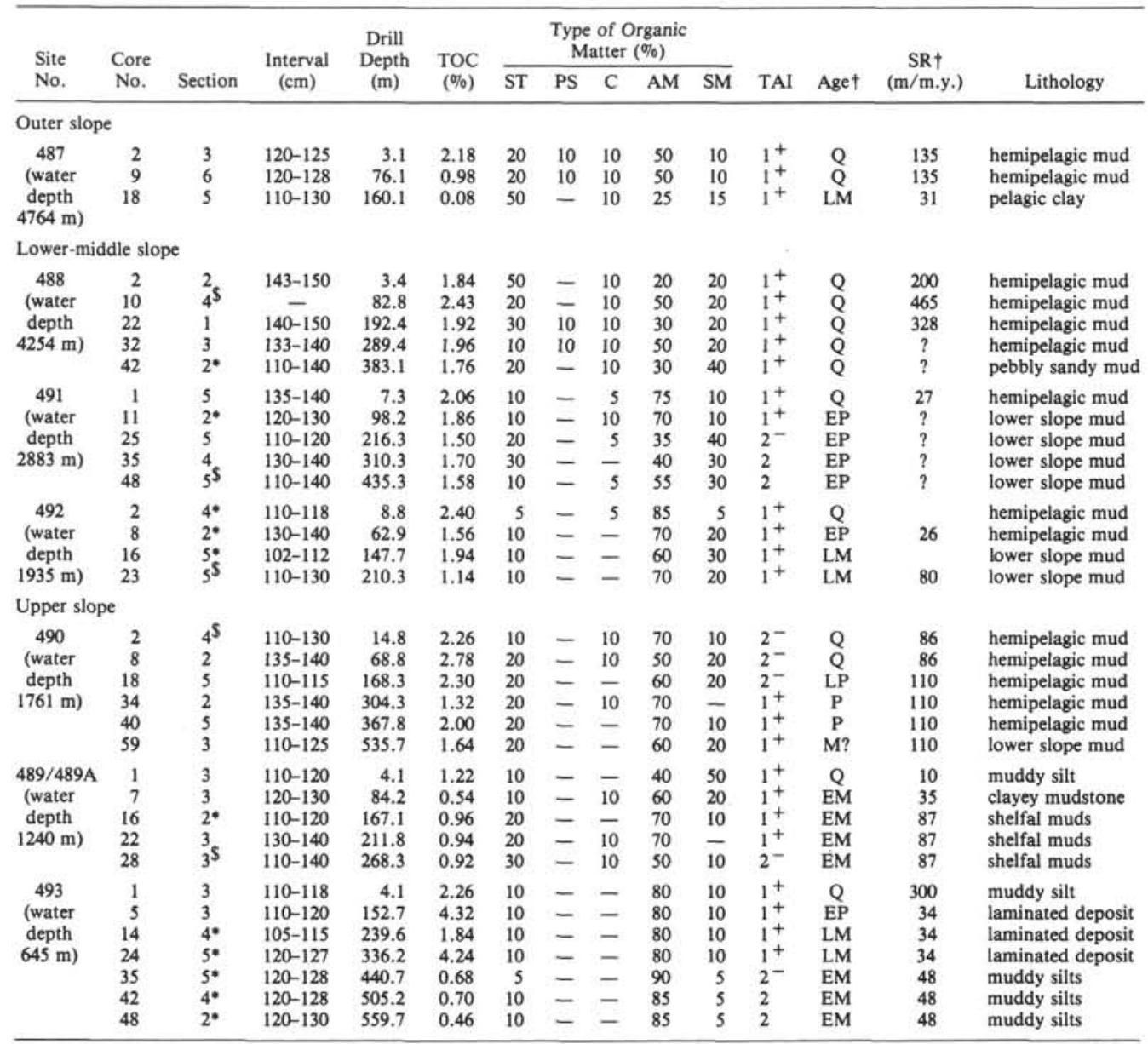

Note: $\mathrm{Q}=$ Quaternary, $\mathrm{EP}=$ early Pliocene, $\mathrm{LP}=$ late Pliocene, $\mathrm{EM}=$ early Miocene, $\mathrm{MM}=$ middle Miocene, $\mathrm{LM}=$ late Miocene. $\mathrm{ST}=$ structured terrestrial, $\mathrm{PS}=$ pollen and spores, $\mathrm{C}=$ charcoal, $\mathrm{AM}=$ amorphous, $\mathrm{SM}=$ structured marine types of organic matter, analyzed by methods described by Masran and Pocock (in press). ${ }^{*}=$ sample analyzed by pyrolysis, $\dagger=$ data from site summaries, $\$$ = sample analyzed by liquid chromatography.

Table 2. Average organic matter type compositions (OMT) and maximum TOC values for different time slices.

\begin{tabular}{|c|c|c|c|c|c|c|c|c|}
\hline \multirow[b]{2}{*}{ Site No. } & \multirow{2}{*}{$\frac{\text { Trench }}{487}$} & \multicolumn{3}{|c|}{ Low-Mid Slope } & \multicolumn{3}{|c|}{ Upper Slope } & \\
\hline & & $488^{*}$ & 491 & 492 & 490 & $489^{* *}$ & 493 & \\
\hline TOC & 2.18 & $2.43(1.76)$ & 2.06 & 2.40 & 2.78 & 1.22 & 2.26 & \multirow{5}{*}{ Quaternary } \\
\hline \multirow[t]{3}{*}{ OMT } & $40 \mathrm{~T}$ & $50 \mathrm{~T}(30 \mathrm{~T})$ & $15 \mathrm{~T}$ & $10 \mathrm{~T}$ & $25 \mathrm{~T}$ & $10 \mathrm{~T}$ & $10 \mathrm{~T}$ & \\
\hline & $50 \mathrm{~A}$ & $30 \mathrm{~A}(30 \mathrm{~A})$ & $75 \mathrm{~A}$ & $85 \mathrm{~A}$. & $60 \mathrm{~A}$ & $40 \mathrm{~A}$ & $80 \mathrm{~A}$ & \\
\hline & $10 \mathrm{M}$ & $20 \mathrm{M}(40 \mathrm{M})$ & $10 \mathrm{M}$ & $5 \mathrm{M}$ & $15 \mathrm{M}$ & $50 \mathrm{M}$ & $10 \mathrm{M}$ & \\
\hline SR & 135 & $2-400$ (?) & 27 & - & 86 & $10 ?$ & $300 ?$ & \\
\hline TOC & & & 1.86 & 1.56 & 2.30 & & 4.32 & \multirow{5}{*}{ Pliocene } \\
\hline \multirow[t]{3}{*}{ OMT } & & & $25 \mathrm{~T}$ & $10 \mathrm{~T}$ & $25 \mathrm{~T}$ & & $10 \mathrm{~T}$ & \\
\hline & & & $50 \mathrm{~A}$ & $70 \mathrm{~A}$ & $65 \mathrm{~A}$ & & $80 \mathrm{~A}$ & \\
\hline & & & $25 \mathrm{M}$ & $20 \mathrm{M}$ & $10 \mathrm{M}$ & & $10 \mathrm{M}$ & \\
\hline SR & & & & 26 & 110 & & 33 & \\
\hline TOC & 0.08 & & & 1.94 & 1.64 & & 4.24 & \multirow{5}{*}{ upper Miocene } \\
\hline \multirow[t]{3}{*}{ OMT } & $60 \mathrm{~T}$ & & & $10 \mathrm{~T}$ & $20 \mathrm{~T}$ & & $10 \mathrm{~T}$ & \\
\hline & $25 \mathrm{~A}$ & & & $65 \mathrm{~A}$ & $60 \mathrm{~A}$ & & $80 \mathrm{~A}$ & \\
\hline & $15 \mathrm{M}$ & & & $25 \mathrm{M}$ & $20 \mathrm{M}$ & & $10 \mathrm{M}$ & \\
\hline SR & 31 & & & 80 & 110 & & 34 & \\
\hline TOC & & & & & & 0.96 & 0.70 & \multirow{5}{*}{ lower-middle Miocene } \\
\hline \multirow{3}{*}{ OMT } & & & & & & $20 \mathrm{~T}(30 \mathrm{~T})$ & $10 \mathrm{~T}$ & \\
\hline & & & & & & $60 \mathrm{~A}(60 \mathrm{~A})$ & $85 \mathrm{~A}$ & \\
\hline & & & & & & $20 \mathrm{M}(10 \mathrm{M})$ & $5 \mathrm{M}$ & \\
\hline SR & & & & & & 3587 & 48 & \\
\hline
\end{tabular}

Note: Compositions are averages calculated from data in Table 1. Sedimentation rates $(\mathrm{m} / \mathrm{m} . \mathrm{y}$.) are from Site Summaries. $T=S T$, PS, and $C$ from Table 1; $A=A M$ from Table $1 ; M=S M$ from Table 1.

- ( ) denotes basal layer of trench sediments as opposed to hemipelagic slope muds.

* ( ) denotes basal layer of shelfal sediments as opposed to hemipelagic slope muds. 
the similarity of Quaternary organic facies between Sites 487 and 488 (Tables 1 and 2) suggest that the same process of deposition operated at both sites.

These samples are moderately enriched in organic matter, with up to $2.0 \%$ to $2.5 \%$ and usually more than $1 \%$ TOC (Table 1). Using data from the site summaries we calculate that the average TOC for Site 488 is $1.6 \%$. TOC's seem to be highest near the surface (Table 1).

\section{Channel Facies}

At the base of Hole 488 is a pebbly sand unit that may have been deposited in channels on the slope or in the trench and then uplifted (see site chapter for Site $488)$. TOC is moderately high $(1.76 \%)$. Like the overlying trench muds, this unit has an equal balance of terrestrial and amorphous material; unlike the younger deposits, it has a large amount of structured marine material (Tables 1 and 2). These sands probably originated on the shelf.

\section{Slope Facies}

In sites shallower than 488 , on the continental slope above the trench (Fig. 1), there do not seem to be any strong regional or stratigraphic patterns in the distribution of organic facies (Tables 1 and 2). The Quaternary deposits are quite variable: some have a strongly amorphous facies, as at Sites 491, 492, and 493; others have an amorphous facies with significant amounts of terrestrial material, as at Site 490; and yet others have a marine and amorphous mixture, as at Site 489 (Table 2). We find highly amorphous samples both on the innermost slope (Site 493) and on the lower slope (Site 491).

The older section contains mid- to lower-slope sediments that have been tectonically raised to their present water depths (See site chapters). These sediments have a remarkably uniform organic facies (see Table 2, Site 491, Pliocene; Sites 492 and 490, upper Miocene; and Site 489 , lower Miocene). This facies averages $10 \%$ to $25 \%$ terrestrial material, $50 \%$ to $65 \%$ amorphous material, and $20 \%$ to $25 \%$ marine material (Table 2). The terrestrial content is low, as it was again later during the Quaternary on the mid-lower slope. These deposits differ from most of the Quaternary sediments in having slightly less amorphous and more structured marine organic matter (Table 2). The overlying sediments are Pliocene (at Sites 492, 490, and 493) and upper Miocene (at Site 493) and tend to be more like most of the Quaternary deposits in being dominated by amorphous material (Table 2).

With few exceptions, the slope sediments are moderately enriched in organic matter (Table 1). Only the lower Miocene of Site 493 consistently contains less than $1 \%$ TOC. At most sites the richest samples contain about 2\% TOC, and there is a tendency for TOC's to be highest in the youngest part of the section (this is seen in our data and in the site chapters). Using data from the site summaries, we calculate that the average TOC for slope sediments is about $1.3 \%$. We see no change in TOC in relation to sedimentation rate (Table 2).
There are higher TOC values $(>4 \%)$ at Site 493 , in the Pliocene and upper Miocene section, where the sediments are laminated. The laminations show that deposition took place within the oxygen minimum zone at a time when bottom waters did not contain enough oxygen to support a large population of benthic organisms. Because oxygen was low, organic matter was preserved.

\section{PYROLYSIS AND C $\mathrm{C}_{15}$ - DATA}

Fifteen samples were analyzed by pyrolysis (Table 3), using standard techniques like those described by Tissot and Welte (1978) and Hunt (1979). Pyrolysis lets us evaluate empirically the likelihood that a given sample will yield oil or gas and whether the yield will be high or low (Table 3). Five of these samples were analyzed, by methods described by McIver (1972), for the components in the heavy $\left(\mathrm{C}_{15}+\right)$ extractable bitumen fraction (Table 4). Comparing the TOC (Table 1) and extractable bitumen data (Table 4) allows us empirically to infer the oil- vs. gas-proneness of each sample and the likely magnitude of the eventual yield (Table 4). At normal levels of maturation, marine-derived material (from seaweed, planktonic organisms, algae, etc.) is expected to yield mostly oil, whereas terrestrially derived organic matter (from the higher land plants) yields mostly gas (Tissot and Welte, 1978; Hunt, 1979). Spores and pollen yield both oil and gas.

Most of the samples analyzed proved to be oil-prone and to have moderate to high potential yields (Tables 3 and 4). Only three of 15 samples chemically analyzed were gas-prone (Tables 3 and 4). The pyrolysis and $\mathrm{C}_{15}+$ data indicate that the amorphous material that dominates the sediments must be derived largely from marine organisms rather than from terrestrial higher land plants.

Our overall rating of the source potential of the section is that it would be good for oil. Where TOC's exceed $2 \%$, it may be very good for oil. Where TOC's are $0.5 \%$ or less, prospects for oil generation would be ex-

Table 3. Results of pyrolysis analyses.

\begin{tabular}{lcccccc}
\hline $\begin{array}{l}\text { Hole } \\
\text { No. }\end{array}$ & $\begin{array}{c}\text { Core } \\
\text { No. }\end{array}$ & Section & $\begin{array}{c}\text { Interval } \\
(\mathrm{cm})\end{array}$ & $\begin{array}{c}\text { Drill } \\
\text { Depth } \\
(\mathrm{m})\end{array}$ & Potential & $\begin{array}{c}\text { Oil- vs. } \\
\text { Gas-Prone }\end{array}$ \\
\hline 488 & 10 & 4 & - & 82.8 & good & oil \\
488 & 42 & 2 & $110-140$ & 383.1 & good & oil \\
$489 \mathrm{~A}$ & 16 & 2 & $110-120$ & 107.1 & good & gas \\
$489 \mathrm{~A}$ & 28 & 3 & $110-140$ & 268.3 & good & oil \\
490 & 2 & 4 & $110-130$ & 14.8 & good & oil \\
491 & 11 & 2 & $120-130$ & 98.2 & good & oil \\
491 & 48 & 5 & $110-140$ & 435.3 & good & oil \\
492 & 2 & 4 & $110-118$ & 8.8 & good & oil \\
492 & 8 & 2 & $130-140$ & 62.9 & good & oil \\
492 & 16 & 5 & $102-112$ & 147.7 & good & gas \\
492 & 23 & 5 & $110-130$ & & good & oil \\
493 & 14 & 4 & $105-115$ & 239.6 & good & oil \\
493 & 24 & 5 & $120-127$ & 336.2 & good & oil \\
493 & 42 & 4 & $120-128$ & 505.2 & good & oil \\
493 & 48 & 2 & $120-130$ & 559.7 & fair & gas \\
\hline
\end{tabular}


Table 4. Results of analyses of benzene-methanol $\mathrm{C}_{15}+$ extraction.

\begin{tabular}{|c|c|c|c|c|c|c|c|c|c|c|c|}
\hline \multirow{2}{*}{$\begin{array}{l}\text { Hole } \\
\text { No. }\end{array}$} & \multirow{2}{*}{$\begin{array}{l}\text { Core } \\
\text { No. }\end{array}$} & \multirow[b]{2}{*}{ Section } & \multirow{2}{*}{$\begin{array}{c}\text { Total } \\
\text { HC } \\
(\mathrm{ppm})\end{array}$} & \multirow{2}{*}{$\begin{array}{l}\mathrm{HC} \\
\% \text { of } \\
\text { TOC }\end{array}$} & \multirow{2}{*}{$\begin{array}{l}\text { Soluble } \\
\text { Organic } \\
\text { Matter } \\
(\mathrm{ppm})\end{array}$} & \multicolumn{4}{|c|}{ Percent of Bitumen } & \multirow[b]{2}{*}{ Potential } & \multirow{2}{*}{$\begin{array}{l}\text { Oil-vs. } \\
\text { Gas-Prone }\end{array}$} \\
\hline & & & & & & $\bar{s}$ & A & NSO & ASPH & & \\
\hline 488 & 10 & 4 & 31 & 0.13 & 658 & 2.2 & 2.5 & 30.3 & 65.0 & good & oil \\
\hline $489 \mathrm{~A}$ & 28 & 3 & 13 & 0.14 & 188 & 3.3 & 3.8 & 28.8 & 64.2 & fair & oil \\
\hline 490 & 2 & 4 & 41 & 0.18 & 574 & 4.5 & 2.7 & 31.3 & 61.6 & good & oil \\
\hline 491 & 48 & 5 & 16 & 0.13 & 362 & 2.0 & 2.2 & 39.6 & 56.1 & good & oil \\
\hline 492 & 23 & 5 & 11 & 0.10 & 388 & 1.3 & 1.5 & 30.1 & 67.1 & good & oil \\
\hline
\end{tabular}

Note: $\mathrm{HC}=$ hydrocarbons; $\mathrm{S}=$ saturated hydrocarbons; $\mathrm{A}=$ aromatic hydrocarbons; $\mathrm{NSO}=$ nitrogen, sulfur, and oxygen compounds; $\mathrm{ASPH}=$ asphaltenes.

tremely poor. As shown in the following, the high potential of the section is not realized in our samples because they have not been cooked enough.

\section{THERMAL ALTERATION}

Spores and pollen in the Quaternary section show no sign of thermal alteration, having thermal alteration indices (TAI) of $1+$ or 2- (Table 1). On a decimalized scale $1+$ would be about 1.3 , and 2 - would be about 1.7. Some of the older samples do show signs of mild thermal alteration. For instance, the TAI increases downhole to values of 2 at Sites 491 and 493 . Generally, however, there is no correlation between TAI and either age or burial depth. Lack of maturation in the older sediments in the drilled section reflects not only the coolness of the area but also their history of tectonic uplift and relative lack of burial.

According to the site summaries the sediments do not contain much gas. Most of what they do contain is methane, probably generated biologically, not thermally. This agrees with our interpretation of the TAI's. The only sites at which significant amounts of wet gas (ethane through butane) were detected were $490\left(\mathrm{C}_{3}-\mathrm{C}_{5}\right.$ up to $\left.879 \mathrm{ppm} ; \mathrm{C}_{2} / \mathrm{C}_{1}=0.003\right)$ and $489\left(\mathrm{C}_{3}-\mathrm{C}_{5}\right.$ up to $4362 \mathrm{ppm}$ ) (site summaries). These hydrocarbons may have migrated into the shallow section from a more deeply buried, more mature part of the section where thermal alteration is producing wet gas and gasolines.

\section{DISCUSSION}

\section{Origin of Organic Facies}

We recognize four main organic facies on the Pacific margin of southern Mexico: one in deep sea pelagic sediments, one in hemipelagic continental slope sediments, one in trench sediments, and one in channel fill.

Organically impoverished, Miocene pelagic clays that are being transported landward on the downgoing Cocos Plate have a strongly terrestrial organic facies that is the end product of organic deposition in the deep sea. As in the deep North Atlantic (Aizenshtat et al., 1973; Summerhayes, 1980), labile marine organic matter has been decomposed by bacteria, leaving small amounts mainly of refractory terrestrial material. Bacterial decay at these depths is particularly effective because the rates of sedimentation are very slow.

On the continental slope are hemipelagic sediments that have an amorphous-dominated organic facies.
These sediments were probably deposited from turbid suspension in flows moving slowly down the slope. Most of the amorphous material seems to be derived from marine organic matter. This facies is quite different from the terrestrial facies that dominates hemipelagic sediments in a similar setting on the continental margin of Japan (Gilbert et al., 1980). There the average organic assemblage is $15 \%$ structured marine, $10 \%$ amorphous, and $75 \%$ terrestrial. TOC's too are different. They average about $1.5 \%$ off Mexico and only $0.7 \%$ off Japan.

Sediments similar to those of the southern Mexican margin do occur on the continental margins of northern Mexico (in the Gulf of California) and in the California Borderland. For instance, the TOC-rich sediment from the oxygen-minimum zone at Site 493 is like that from the oxygen-minimum zone in both the California Borderland (Gilbert and Summerhayes, in press a) and in the Gulf of California (Gilbert and Summerhayes, in press b). The less-TOC-rich sediments of the rest of the slope of southern Mexico are like the moderately rich sediments from water depths below the oxygen minimum on the Baja California margin in the Gulf of California (Gilbert and Summerhayes, in press b) and the pre-upper Miocene sediments from the California Borderland (Gilbert and Summerhayes, in press a).

How do we account for the preservation of substantial amounts of organic matter in these different settings? The first requirement seems to be a high rate of supply of marine organic matter. This is ensured in environments where there is extensive upwelling and high productivity, as in much of the eastern central Pacific. The second requirement is an oxygen-minimum zone containing little or no oxygen. Demaison and Moore (1980) give evidence to show that most preservation takes place in the anaerobic zone where oxygen is less than $0.5 \mathrm{ml} / \mathrm{l}$; some organic matter can also be preserved in a dysaerobic zone where oxygen levels are a little less low $(0.5-1.0 \mathrm{ml} / \mathrm{l})$; where oxygen is more than $1 \mathrm{ml} / 1$, most labile organic matter is oxidized and destroyed. Within the oxygen-minimum zone in the Pacific, severe depletion in oxygen is common along the American margin from Chile to Oregon (Kester, 1975). The general oxygen depletion of this dysaerobic region, coupled with moderately high rates of sedimentation (i.e., rates of burial of organic matter), probably explains why most slope sediments contain $1 \%$ to $2 \%$ TOC. The severe depletion of oxygen in the anaerobic 
zone at the peak of the oxygen-minimum zone along this coast explains the extensive enrichment in organic matter on the uppermost slope (Calvert, 1964; Demaison and Moore, 1980; Gilbert and Summerhayes, in press a, b). Off Japan, in contrast, the water mass (including the oxygen-minimum zone) is well oxygenated (Kester, 1975); as a result, preservation of labile marine material is poor and we are left mainly with the more refractory terrestrial components (Gilbert et al., 1980).

Bacterial activity may modify diagenetically both the organic facies and the TOC, as shown, for example, by Emery (1960), who pointed out the preferential loss of nitrogenous over carbonaceous organic materials with burial in the California Borderland. Bacteria attack first the most labile components, like the organic remains of marine plants (cf. Aizenshtat et al., 1973). Bacterial activity may account, therefore, both for the downhole decrease in TOC that we see at most slope sites (excluding Site 493, where the organic patterns are modified by the presence of the oxygen-minimum zone) and the corresponding downhole change from highly amorphous at surface to a less amorphous and more terrestrial facies at depth (Table 2). Alternatively, this change could be a response to changes in preservation or deposition. For instance, bottom waters in the past may have carried more oxygen than they do today, thus preserving less marine amorphous organic matter and causing a slight lowering in the TOC. Or a slight change in depositional processes may have led to a different input ratio of marine to terrestrial material in the past. More work is needed to solve this question.

The trench sediments have a more terrestrial and less amorphous organic facies than the slope sediments, though both carry about the same amounts of organic matter. Terrestrial organic matter is unlikely to increase in abundance downslope away from source if the means of transportation is slow downhill movement of turbid water from the shelf edge. Therefore when we find large amounts of terrestrially derived organic matter in deep water, it is usually the result of along-slope transport of material brought to the base of the slope in fast-moving turbidity currents, as on the Mississippi Cone (Newman et al., 1973) and in the Guaymas Basis in the center of the Gulf of California (Gilbert and Summerhayes, in press b). Lateral transport along the axis of the Middle America Trench must account for the distribution of terrestrial organic matter at Sites 487 and 488 .

As mentioned in the foregoing, the channel facies (our fourth main organic facies) is also "introduced" in the sense of having been transported from shallow water, probably by fast-moving turbidity currents. It is different from its fine-grained counterparts, the trench muds, in having a lot of structured marine materialprobably the remains of seaweed. In keeping with the concept of shallow-water origin, this facies has a higher terrestrial/amorphous ratio than do the nearby slope sediments (Table 2).

The downhole distribution of organic matter may tell us something about the history of oxygenation of Pacific slope waters. The low TOC's at Sites 489 and 493 in the lower Miocene (Table 2) suggest that slope waters were quite well oxygenated at that time. In the upper Miocene, sediments contain more organic matter, suggesting a general depletion of oxygen at all water depths and an especially severe decrease on the upper slope (in the oxygen minimum zone). We see this same pattern in the California Borderland (Gilbert and Summerhayes, in press a). The pattern is attributed to strong development of the oxygen minimum at the end of the middle Miocene in response to climatic shifts caused by development of an Antarctic ice cap (Gilbert and Summerhayes, in press a).

\section{Hydrocarbon Potential}

The slope and trench facies both have good potential for the generation of liquid hydrocarbons. The potential here is much higher than on the continental margin of Japan, although the physical setting is similar. There are some grounds for believing that organically enriched sediments within the section will tend to be upper Miocene or younger. Probably the richest sediments in the section will be those that were deposited within the boundaries of the oxygen minimum zone since the middle Miocene.

The drilled section is immature and not capable of generating liquid hydrocarbons. There may be substantial amounts of biogenic gas in this area. If, at depth on the slope, there are thermally mature equivalents of the analyzed slope sediments, oil should have been generated. But if much of the buried section consists of uplifted equivalents of (1) the organically impoverished pelagic clays from Site 487 or (2) the organic poor hemipelagic sediments from the lower Miocene of Sites 489 and 493, substantial oil generation is unlikely. These sediments contain too little material to be considered good sources for commercial quantities of gas or oil.

\section{CONCLUSIONS}

Substantial amounts of organic matter are being deposited on the southern continental margin of Mexico and in the Middle America Trench. On the slope most of the organic matter seems to be derived from the remains of marine organisms. In contrast, trench and channel fill sediments contain substantial amounts of the remains of higher land plants. Buried Miocene pelagic sediments on the downgoing Cocos Plate have little organic matter, much of it the refractory remains of terrestrial land plants. Enrichment in organic matter peaked in the late Miocene and Pliocene on the uppermost continental slope within the oxygen minimum zone. Before the late Miocene, slope sediments contained much less organic matter.

We interpret these patterns in terms of (1) depositional processes and (2) the history of oxygenation of the eastern Pacific water mass. Depositional processes control organic facies as follows. Terrestrial organic matter is transported to the trench in fast-moving turbidity currents that originate near the coast. This material bypasses the slope and is distributed within the trench by currents moving along the trench axis. In contrast, slow downslope movement of turbid water controls hemipelagic sedimentation on the slope and brings 
in mainly marine organic matter that originates on the outer shelf (away from the terrestrial influence of the coast) and in surface waters over the slope. Burial is rapid, so that marine organic matter is not subjected to much oxygenation. This is not so in deep water in the open Pacific, where slow deposition permits much of the marine component to be oxidized, leaving a small residue mainly of refractory terrestrial components (we think that the Miocene pelagic sediments are representative of what happens today out on the Cocos Plate).

Water chemistry controls organic richness as follows. In mid- to early-Miocene times the eastern Pacific was not the area of intensive upwelling and high productivity that it is today. As a result the water mass contained more oxygen than it does today, and little organic matter accumulated on the slope. In the late Miocene, changes in circulation led to an increase in upwelling and productivity, and the subsurface waters became depleted in oxygen. Where this depletion was severe, as in the oxygen minimum on the uppermost slope, substantial amounts of organic matter were preserved. Where oxygen depletion was less severe, apparently over most of the slope, there was less preservation. Since TOC's are much higher than on the well-oxidized Japan margin, we suspect that oxygen levels off Mexico were always less than they are off Japan.

The late Miocene and younger sediments have good potential for the generation of liquid hydrocarbons, but those drilled have not yet been cooked enough to have yielded any liquids. Because the sediments are moderately rich in organic matter, they may contain substantial amounts of biogenically derived methane. If the deep section consists mostly of TOC-poor sediments like the Miocene pelagic clays and the lower Miocene hemipelagic muds, the potential for oil will not be high.

\section{ACKNOWLEDGMENTS}

Chemical analyses were made at Exxon Production Research Company, by Harvey Fry, Alan Everett, and E. E. Brown. D. Gilbert made the kerogen analyses and determined the thermal alteration indices. We thank Exxon Production Research Company for continued support of this work and for permission to publish these results. W. A. Young and J. P. Shannon reviewed the manuscript.

\section{REFERENCES}

Aizenshtat, Z., Baedecker, M. T., and Kaplan, I. R., 1973. Distribution and diagenesis of organic compounds in JOIDES sediment from Gulf of Mexico and Western Atlantic. Geochim. Cosmochim. Acta, 37:1881-1898.

Calvert, S. E., 1964. Factors affecting distribution of laminated diatomaceous sediments in Gulf of California. In van Andel, Tj. H., and Shor, G. G. (Eds.), Marine Geology of the Gulf of California, 3: Tulsa (American Association of Petroleum Geologists), 311330.

Demaison, G. J., and Moore, G. T., 1980. Anoxic environments and oil source bed genesis. Organic Geochem., 2:9-31.

Emery, K. O., 1960. The Sea off Southern California: New York (Wiley).

Gilbert, D., and Summerhayes, C. P., in press a. Distribution of organic matter in sediments along the Californian continental margin. In Yeats, R. S., Haq, B. U., et al., Init. Repts. DSDP, 63: Washington (U.S. Govt. Printing Office).

in press b. Organic facies and hydrocarbon potential in the Gulf of California. In Curray, J. R., Moore, D. G., et al., Init. Repts. DSDP, 64: Washington (U.S. Govt. Printing Office).

Gilbert, D., Summerhayes, C. P., and Johnson, D. L., 1980. Nature, origin, and petroleum source potential of organic matter from DSDP Sites $434,435,438$, and 440 in the Japan Trench. In Scientific Party, Init. Repts. DSDP, 56, 57, Pt. 2: Washington (U.S. Govt. Printing Office), 1327-1330.

Hunt, J. M., 1979. Petroleum Geochemistry and Geology: San Francisco (W. H. Freeman).

Kester, D. R., 1975. Dissolved gases other than $\mathrm{CO}_{2}$. In Riley, J. P., and Skirrow, G. (Eds.), Chemical Oceanography: New York (Academic Press), pp. 498-556.

McIver, R. D., 1972. Geochemical significance of gas and gasolinerange hydrocarbons and other organic matter in a Miocene sample from Site 134-Balearic abyssal plain. In Ryan, W. B. F., Hsü, K., et al., Init. Repts. DSDP, 13: Washington (U.S. Govt. Printing Office), 813-816.

Masran, Th. C., and Pocock, S. A. J., in press. Classification of plant-derived particulate organic matter in sedimentary rocks. In Staplin, F. L. (Ed.), Kerogen-visual and Chemical Relationships, A Symposium: Dallas (Am. Assoc. Strat. Palynol.).

Moore, J. C., Watkins, J. S., Bachman, S. B., et al., 1979. Middle America Trench. Geotimes, September: 20-22.

Newman, J. W., Parker, P. L., and Behrens, E. W., 1973. Organic carbon isotope ratios in Quaternary cores from the Gulf of Mexico. Geochim. Cosmochim. Acta, 37:225-238.

Staplin, F. L., 1969. Sedimentary organic matter, organic metamorphism and oil and gas occurrence. Bull. Can. Petrol. Geol., 17:47-66.

Summerhayes, P. C., 1980. Organic facies of mid-Cretaceous black shales in the deep North Atlantic. SEPM Research Symposium: Hydrocarbon source beds, their depositional environments and early diagenesis. Annual Mtg. AAPG, Denver. Bull. Am. Assoc. Pet. Geol., 64(5):790. (Abstract)

Tissot, B. P., and Welte, D. H., 1978. Petroleum Formation and Occurrence: New York (Springer-Verlag). 